Article

\title{
Effects of Sodium Phosphate and Sodium Nitrite on the Pitting Corrosion Process of X70 Carbon Steel in Sodium Chloride Solution
}

\author{
Yongyan Zhu ${ }^{1, *}$, Jiayi Ding ${ }^{1}$, Jianli Zhang ${ }^{2}$ and Liang $\mathrm{Li}^{1}$ \\ 1 Jiangsu Key Laboratory of Green Synthetic Chemistry for Functional Materials, \\ School of Chemistry and Materials Science, Jiangsu Normal University, Xuzhou 221116, China; \\ OKOKdingjiayi@163.com (J.D.); lil@jsnu.edu.cn (L.L.) \\ 2 Jiangsu Zhongneng Silicon Industry Technology Development Co., Ltd., Xuzhou 221116, China; \\ zhangjianli@gcl-power.com \\ * Correspondence: zhuyongyan@jsnu.edu.cn; Tel.: +86-0516-8353-6538
}

Received: 16 October 2020; Accepted: 23 November 2020; Published: 27 November 2020

\begin{abstract}
In this paper, effects of sodium phosphate $\left(\mathrm{Na}_{3} \mathrm{PO}_{4}\right)$ and sodium nitrite $\left(\mathrm{NaNO}_{2}\right)$ on the pitting corrosion of $X 70$ carbon steel in $0.10 \mathrm{~mol} / \mathrm{L} \mathrm{NaCl}$ solution were investigated by potentiodynamic polarization technique, electrochemical impedance spectroscopy (EIS) method, scanning electron microscope (SEM) and scanning electrochemical microscope (SECM). The SECM equipment was used to observe the dynamic processes of the pitting corrosion in situ. $\mathrm{Na}_{3} \mathrm{PO}_{4}$ or $\mathrm{NaNO}_{2}$ in the sodium chloride solution decreased the local anodic dissolution and increased the pitting resistance of the specimen. By analysis and comparison, it can be concluded that the inhibition effect of $\mathrm{Na}_{3} \mathrm{PO}_{4}$ is mainly due to the formation of a salt film, while the corrosion inhibition of $\mathrm{NaNO}_{2}$ is principally attributed to a protective oxide film on the electrode surface.
\end{abstract}

Keywords: corrosion inhibitor; pitting corrosion; anodic dissolution; scanning electrochemical microscope (SECM); carbon steel

\section{Introduction}

When X70 carbon steel is in a corrosive environment, passive film on its surface breaks down at local points. At these points, electrodissolution takes place while the rest of the surface remains passive. Thus, pitting corrosion occurs [1-9].

Using inhibitors is one of the corrosion prevention methods among others. It has been found that some inorganic anions can inhibit pitting corrosion of metals or alloys in corrosive environment. The inhibition effects and mechanisms of the anions have been studied by methods of weight loss and electrochemical measurements for more than 60 years [10-29]. However, there are still many controversies about the inhibition mechanisms of the anions. Sodium phosphate $\left(\mathrm{Na}_{3} \mathrm{PO}_{4}\right)$ is usually considered as an effective corrosion inhibitor for metals in the corrosive environments containing $\mathrm{Cl}^{-}$ions. For example, Refaey et al. $[10,11]$ found that $\mathrm{Na}_{3} \mathrm{PO}_{4}$ had strong inhibition effects on the pitting corrosion of mild steel in sodium chloride $(\mathrm{NaCl})$ solution and in hydrochloric acid $(\mathrm{HCl})$ solution. Zuo et al. [12] investigated the inhibition effects of $\mathrm{Na}_{3} \mathrm{PO}_{4}$ by using potentiodynamic and potentiostatic polarization measurements and proposed that $\mathrm{Na}_{3} \mathrm{PO}_{4}$ inhibited the pitting corrosion of 316L SS in $\mathrm{NaCl}$ solution by retarding both the nucleation and the propagation of metastable pits. As an inhibitor, $\mathrm{Na}_{3} \mathrm{PO}_{4}$ has the advantage of relatively low cost and toxicity in comparison with sodium chromate $\left(\mathrm{Na}_{2} \mathrm{CrO}_{4}\right)$ and sodium nitrite $\left(\mathrm{NaNO}_{2}\right)$. $\mathrm{NaNO}_{2}$ is also considered as a good inhibitor for the pitting corrosion of metals or alloys [10,13-18]. Refaey et al. [10] found that $\mathrm{NaNO}_{2}$ had strong inhibition effects on the pitting corrosion of the steel samples induced by $\mathrm{Cl}^{-}$ions. Fujioka et al. [16] 
proposed that $\mathrm{NO}_{2}{ }^{-}$ions suppressed both pit nucleation and pit propagation for a passivated iron electrode in an aerated borate buffer solution containing $\mathrm{Cl}^{-}$ions at $\mathrm{pH}$ 8.49. Although many studies concerning the inhibition effects of $\mathrm{Na}_{3} \mathrm{PO}_{4}$ and $\mathrm{NaNO}_{2}$ have been reported, the impacts of these inhibitors on the dynamic processes of pitting corrosion are rarely reported.

Scanning electrochemical microscope (SECM) has been already used to study localized corrosion, such as the pitting corrosion of $\mathrm{X70}$ carbon steel in $\mathrm{NaCl}$ solution and so on [30-32]. It can provide useful information about the corrosion behavior at a microscopic level. During the pitting corrosion processes, there are more $\mathrm{Fe}^{2+}$ ions around the pits, so when a suitable polarization potential is applied to the probe electrode, the magnitude of the oxidation current can reflect the initiation and the propagation of the pitting corrosion [30].

In this paper, the inhibition effects of $\mathrm{Na}_{3} \mathrm{PO}_{4}$ and $\mathrm{NaNO}_{2}$ on the pitting corrosion of $\mathrm{X70}$ carbon steel in $0.10 \mathrm{~mol} / \mathrm{L} \mathrm{NaCl}$ solution have been investigated by using potentiodynamic polarization technique, electrochemical impedance spectroscopy (EIS) method, scanning electron microscope (SEM)and SECM. The purpose of this study is to explore the inhibition effects of the two inhibitors on the initiation and the propagation of the pitting corrosion, and to discuss the inhibition mechanisms in depth.

\section{Materials and Methods}

A self-made four-electrode electrochemical cell was used in the SECM measurements (CHI910B electrochemical work station, Shanghai Chenhua Instruments Co., Ltd., Shanghai, China). A stationary X70 carbon steel electrode was used as the substrate electrode, whose chemical composition (in wt.\%) was $0.22 \mathrm{C}, 1.65 \mathrm{Mn}, 0.24 \mathrm{Si}, 0.015 \mathrm{~S}, 0.025 \mathrm{P}$ and Fe balance. The carbon steel rod $(\Phi=5.0 \mathrm{~mm})$ was sealed by epoxy resin in a PTFE tube, leaving only one circular cross section exposed to the electrolyte. Before each measurement, the electrode surface was abraded with No. 600, No. 1200 and No. 2000 sandpaper successively, and then washed in an ultrasonic cleaner by deionized water for $3 \mathrm{~min}$. A platinum plate $\left(1 \times 4 \mathrm{~cm}^{2}\right)$ was used as counter electrode. A saturated calomel electrode (SCE) was used as reference electrode. If there is no special note, all the potentials in this work are referred to the SCE. During the measurements, the specimen was immersed in the solution and faced upwards. A platinum ultramicroelectrode tip (the tip electrode, $\mathrm{d}=25 \mu \mathrm{m}$ ) moved above the specimen. The distance between the substrate and the tip was controlled to be $30 \mu \mathrm{m}$ with the help of a charge coupled device (CCD, TCL Technology Group Co., Ltd., Huizhou, China). The tip potential was 0.65 V, which was based on the tip electrode to monitor $\mathrm{Fe}^{2+}$ ions as the following reaction [30]:

$$
\mathrm{Fe}^{2+}=\mathrm{Fe}^{3+}+\mathrm{e}
$$

All the substrate electrodes were held at the potential of $0.250 \mathrm{~V}$ higher than the open circuit potential $\left(E_{\mathrm{OCP}}\right)$, thus the pitting corrosion processes on the electrode surface could be observed. The scanning area was $200 \times 200 \mu \mathrm{m}$, the increment distance was $20 \mu \mathrm{m}$ and the increment time was $0.5 \mathrm{~s}$. The surface morphology of the electrode was observed by the SEM (Model S-3400N, produced by Hitachi Company, Tokyo, Japan) after the anodic polarization at $0.250 \mathrm{~V}$ (vs. EOCP) in each solution.

The Tafel and EIS curves were obtained by Solartron 1287/1260 (Solartron Analytical, Hampshire, UK). The EIS curves conducted at the $E_{\mathrm{OCP}}$. The frequency range was $0.01-100,000 \mathrm{~Hz}$, and the amplitude was $10 \mathrm{mV}$. The Tafel measurements were carried out positively at the scan rate of $1 \mathrm{mV} / \mathrm{s}$ from $-0.030 \mathrm{~V}$ (vs. $E_{\mathrm{OCP}}$ ) until the current density reached to about $5 \mathrm{~mA} / \mathrm{cm}^{2}$.

All the solutions were prepared from regents of the analytical grade and double distilled water. All the electrochemical measurements were conducted at about $25^{\circ} \mathrm{C}$. 


\section{Results}

\subsection{The Polarization Curves in the $\mathrm{NaCl}$ Solution without and with $\mathrm{Na}_{3} \mathrm{PO}_{4}$ and $\mathrm{NaNO}_{2}$}

Figure 1 shows the Tafel curves of $\mathrm{X} 70$ carbon steel in $0.10 \mathrm{~mol} / \mathrm{L} \mathrm{NaCl}$ solutions without and with $0.020 \mathrm{~mol} / \mathrm{L} \mathrm{Na}_{3} \mathrm{PO}_{4}$ (B) or $0.020 \mathrm{~mol} / \mathrm{L} \mathrm{NaNO}_{2}(\mathrm{C})$. In curve B or $\mathrm{C}$, when the potential was higher than the critical pitting potential $\left(E_{\text {pit }}\right)$, the current density suddenly increased steeply, denoting the rupture of the passive film and the occurrence of the pits on the electrode surface. The presence of $\mathrm{Na}_{3} \mathrm{PO}_{4}$ or $\mathrm{NaNO}_{2}$ brought a marked $E_{\text {pit}}$, which indicated the pitting corrosion was inhibited to an extent by the inhibitors. Figure 2 shows the dependence of the $E_{\text {pit }}$ on the concentrations of $\mathrm{Na}_{3} \mathrm{PO}_{4}$ or $\mathrm{NaNO}_{2}$. As shown in Figure 2, the higher the concentration of the inhibitor, the more positive shift of the $E_{\text {pit }}$ the less favorable condition for the pit initiation.

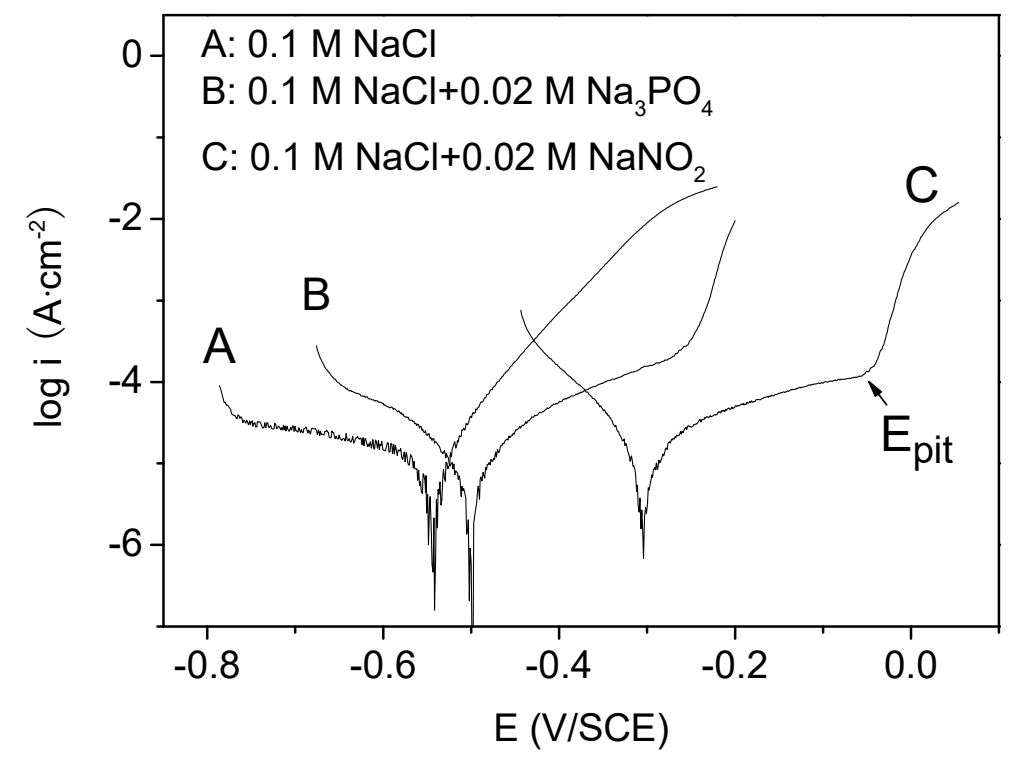

Figure 1. The Tafel curves of $X 70$ carbon steel in various solutions (A) $0.10 \mathrm{~mol} / \mathrm{L} \mathrm{NaCl}$; (B) $0.10 \mathrm{~mol} / \mathrm{L}$ $\mathrm{NaCl}+0.020 \mathrm{~mol} / \mathrm{L} \mathrm{Na}_{3} \mathrm{PO}_{4} ;(\mathrm{C}) 0.10 \mathrm{~mol} / \mathrm{L} \mathrm{NaCl}+0.020 \mathrm{~mol} / \mathrm{L} \mathrm{NaNO}_{2}$.

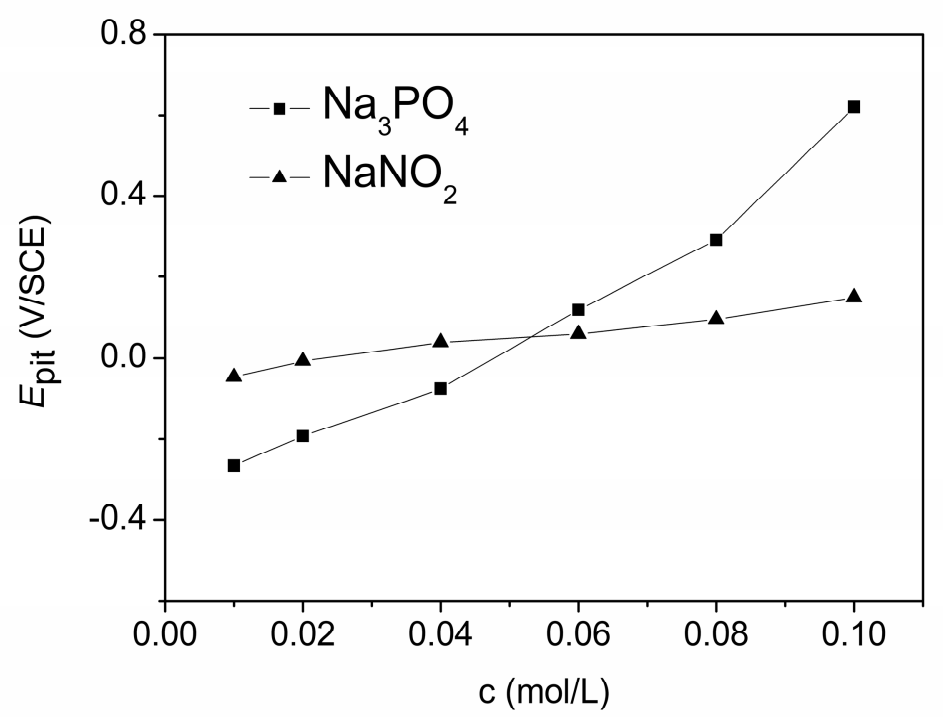

Figure 2. The relationship between the critical pitting potential $\left(E_{\text {pit }}\right)$ and the concentrations of $\mathrm{Na}_{3} \mathrm{PO}_{4}$ or $\mathrm{NaNO}_{2}(\mathrm{c})$. 
However, the Tafel curves could only give overall and indirect information about the inhibition effects. In order to give a clear and satisfactory explanation for the inhibition mechanism, especially the comprehensive information concerning the inhibition effects on the initiation and the propagation of the pitting corrosion, the SECM measurements were carried out. The pitting corrosion of X70 carbon steel in each solution was induced by anodic polarization. In each solution containing $\mathrm{Na}_{3} \mathrm{PO}_{4}$ or $\mathrm{NaNO}_{2}$, the applied potential was a little lower than the $E_{\text {pit }}$, optimal for the observation of the conversion between the metastable pits and the stable pits. During the potentiostatic polarization process, five simultaneous SECM images (The range of the X-axis is $0 \sim 200 \mu \mathrm{m}$, the range of the $Y$-axis is $0 \sim 200 \mu \mathrm{m}$, and the range of the Z-axis is 0 20 nA.) of the specimen had been recorded at about the 10th, 20th, 30th, 40th and 50th min, respectively. Then, the three-dimensional images were exhibited in a figure to observe the dynamic processes of the pitting corrosion. Each current peak in the images stood for a metastable or stable pitting event in the scanned area.

\subsection{The Pitting Corrosion of X70 Carbon Steel in the NaCl Solution}

In order to comparing, the SECM measurements had been firstly carried out in $0.10 \mathrm{~mol} / \mathrm{L}$ $\mathrm{NaCl}$ solution. As shown in Figure $3 \mathrm{~A}-\mathrm{C}$, the specimen was harshly attacked by the chloride ions at $E=-0.320 \mathrm{~V}\left(E_{\mathrm{OCP}}=-0.570 \mathrm{~V}\right)$. Three current peaks (metastable pits or stable pits) were clearly observed at the 10th min after the potential application (A); and both the number and the extent of the pits increased as time goes on (20th $\mathrm{min}, \mathrm{B}$ ). The surface was almost completely active after $30 \mathrm{~min}$ anodic polarization $(\mathrm{C})$. Thus, the dynamic processes of the pitting corrosion on the electrode surface were successfully observed by the SECM measurements. Figure 4A shows the surface morphology of the specimen after $30 \mathrm{~min}$ anodic polarization at the potential of $E=-0.320 \mathrm{~V}$. Obviously, after the polarization, the specimen was severely corroded by the chloride ions in the solution, which is consistent with the SECM image (C) in Figure 3.
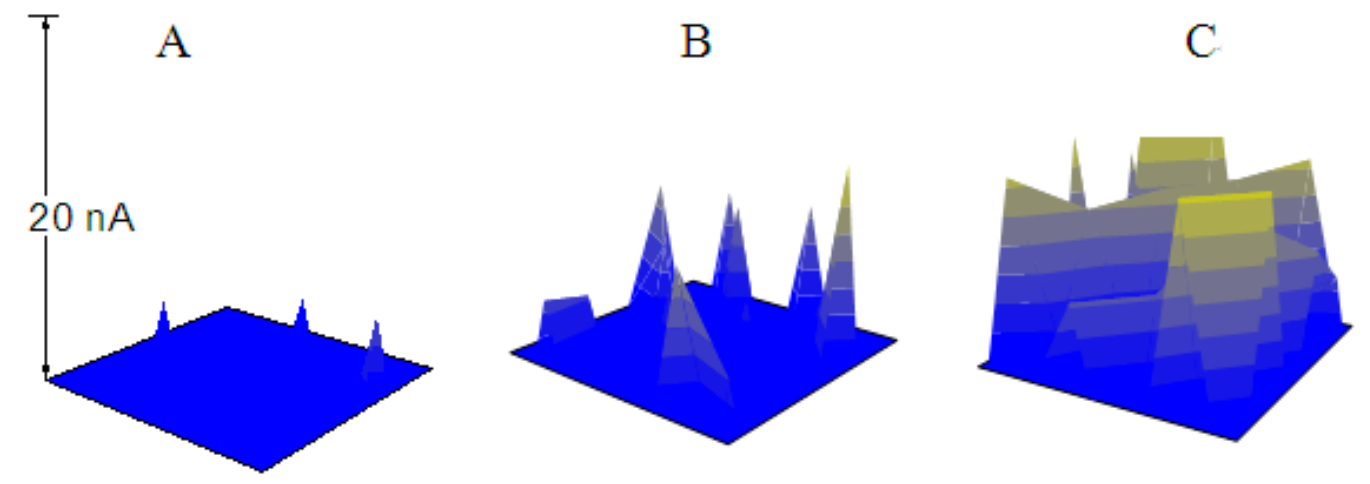

Figure 3. The SECM images of the $\mathrm{X} 70$ carbon steel electrode polarized at $-0.320 \mathrm{~V}\left(E_{\mathrm{OCP}}=-0.570 \mathrm{~V}\right)$ in $0.10 \mathrm{~mol} / \mathrm{L} \mathrm{NaCl}$ solution (A) $10 \mathrm{~min}$; (B) $20 \mathrm{~min}$; (C) $30 \mathrm{~min}$. 

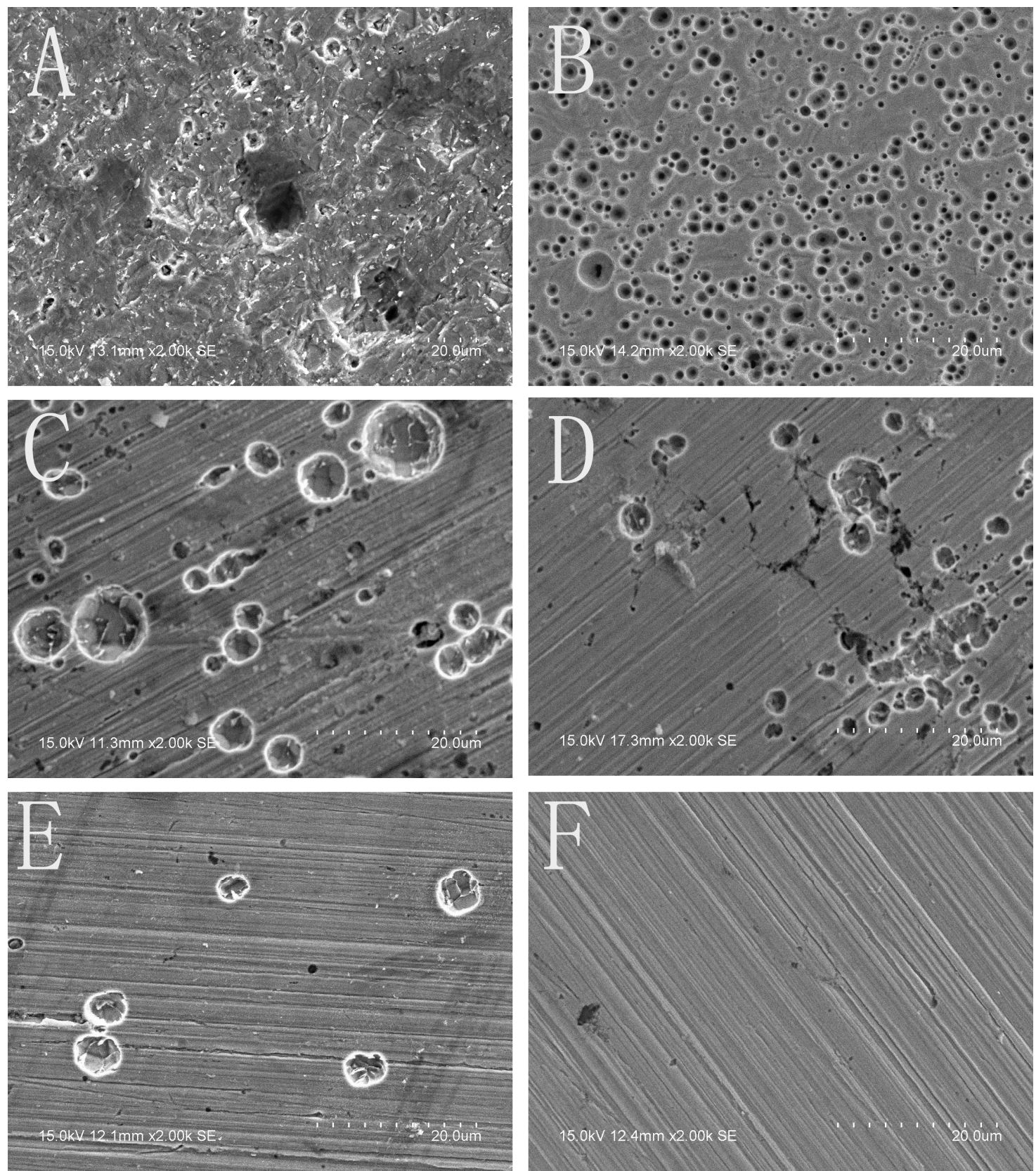

Figure 4. The surface morphology of the $X 70$ carbon steel electrodes after the polarization in various solutions (A) after $30 \mathrm{~min}$ polarization in $0.10 \mathrm{~mol} / \mathrm{L} \mathrm{NaCl}$ solution at $-0.320 \mathrm{~V}\left(E_{\mathrm{OCP}}=-0.570 \mathrm{~V}\right)$; (B) after $50 \mathrm{~min}$ polarization in $(0.10 \mathrm{~mol} / \mathrm{L} \mathrm{NaCl}+0.010 \mathrm{~mol} / \mathrm{L} \mathrm{NaOH})$ solution at $-0.300 \mathrm{~V}$ $\left(E_{\mathrm{OCP}}=-0.550 \mathrm{~V}\right) ;(\mathbf{C}-\mathbf{F})$ after $50 \mathrm{~min}$ polarization in $\left(0.10 \mathrm{~mol} / \mathrm{L} \mathrm{NaCl}+\mathrm{x} \mathrm{mol} / \mathrm{L} \mathrm{Na}_{3} \mathrm{PO}_{4}\right)$ solutions at $-0.290 \mathrm{~V}\left(E_{\mathrm{OCP}}=-0.540 \mathrm{~V}\right)(\mathrm{C}: \mathrm{x}=0.020 ; \mathrm{D}: \mathrm{x}=0.040 ; \mathrm{E}: \mathrm{x}=0.060 ; \mathbf{F}: \mathrm{x}=0.080)$.

\subsection{The Pitting Corrosion of X70 Carbon Steel in the $\mathrm{NaCl}$ Solution with $\mathrm{Na}_{3} \mathrm{PO}_{4}$}

When there was $\mathrm{Na}_{3} \mathrm{PO}_{4}$ in the $\mathrm{NaCl}$ solution, the SECM images were completely different. Figure 5 shows the processes of the pitting corrosion of the specimens at $E_{\mathrm{S}}=-0.290 \mathrm{~V}$ (the $E_{\mathrm{OCP}}$ is about $-0.540 \mathrm{~V}$ ) in $0.10 \mathrm{~mol} / \mathrm{L} \mathrm{NaCl}$ solution containing various concentrations of $\mathrm{Na}_{3} \mathrm{PO}_{4}$. As shown in Figure 5A1-E1), two current peaks at the 10th min (A1) and three current peaks at the 20th min (B1) were observed on the surface of the specimen in the solution with $0.020 \mathrm{~mol} / \mathrm{L} \mathrm{Na} \mathrm{PO}_{4}$. Then, one current peak disappeared; the other two current peaks propagated while another two current peaks emerged (C1). And several pits initiated (D1) and developed to stable pits (E1) after $50 \mathrm{~min}$ 
anodic polarization. The current peak at the 20th min (point "a" in B1) disappeared at the 30th min, and it did not reappear anymore. The current peaks (point " $b$ " and " $c$ " in B1) at the 20th min developed to stable pits and did not disappear all along. One current peak appeared at the 20th min (B2) and two current peaks were observed at the 30th $\mathrm{min}(\mathrm{C} 2)$ in the $\mathrm{NaCl}$ solution containing $0.040 \mathrm{~mol} / \mathrm{L} \mathrm{Na}_{3} \mathrm{PO}_{4}$, while only one current peak occurred at the 30th min in the $\mathrm{NaCl}$ solution containing $0.060 \mathrm{~mol} / \mathrm{L}$ $\mathrm{Na}_{3} \mathrm{PO}_{4}$ (C3). When the concentration of $\mathrm{Na}_{3} \mathrm{PO}_{4}$ increased to $0.080 \mathrm{~mol} / \mathrm{L}$, current peak did not emerge until at the 40th min (D4). These results clearly showed that as the concentration of $\mathrm{Na}_{3} \mathrm{PO}_{4}$ increased, the number and the extent of the pits decreased obviously, and the induced time of the pitting corrosion increased distinctly. Figure 4C-F) shows the surface morphology of the specimens after 50 min anodic polarization at $\mathrm{E}=-0.290 \mathrm{~V}$ in the $\mathrm{NaCl}$ solution containing various concentrations of $\mathrm{Na}_{3} \mathrm{PO}_{4}$. Obviously, the corrosion behavior shown here is consistent with that in the SECM images (Figure 5).

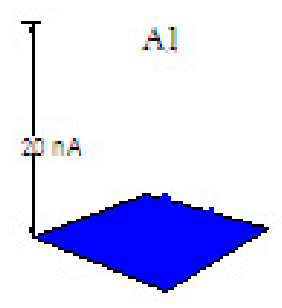

B1
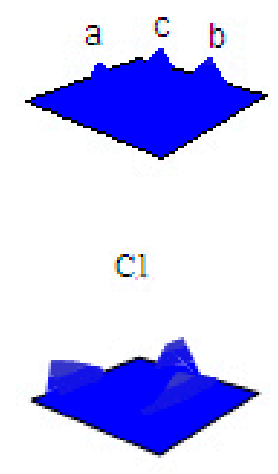

D1

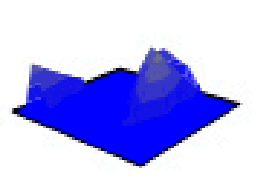

E1

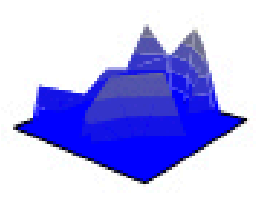

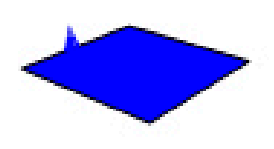

C2

A2

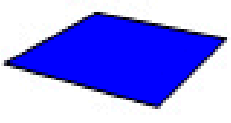

B2

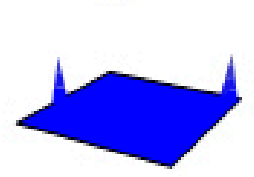

D2

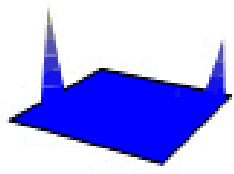

E2

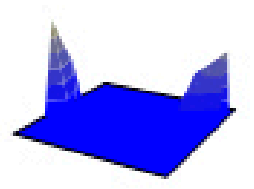

A3

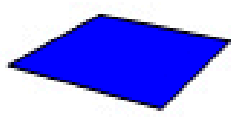

B3

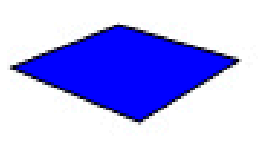

c3

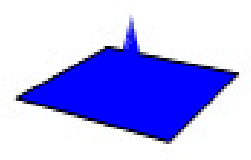

D3

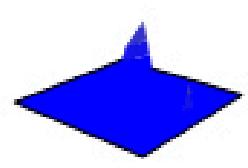

E3

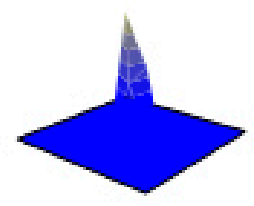

A 4

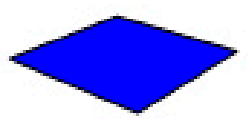

$10 \mathrm{~min}$

B4

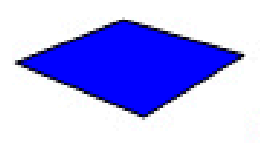

$20 \mathrm{~min}$

C4

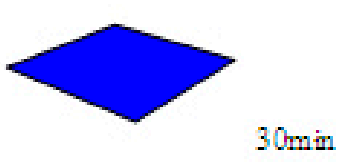

D4

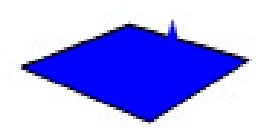

$40 \mathrm{~min}$.

E4

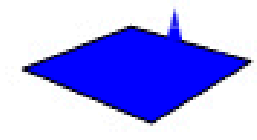

$50 \mathrm{~min}$.

Figure 5. The scanning electrochemical microscope (SECM) images of the $\mathrm{X} 70$ carbon steel electrodes polarized at $-0.290 \mathrm{~V}\left(E_{O C P}=-0.540 \mathrm{~V}\right)$ in $0.10 \mathrm{~mol} / \mathrm{L} \mathrm{NaCl}+\mathrm{x} \mathrm{mol} / \mathrm{L} \mathrm{Na}_{3} \mathrm{PO}_{4}$ solutions $($ A1-E1 $) \mathrm{x}=0.020$; $($ A2-E2) $\mathrm{x}=0.040 ;(\mathrm{A3}-\mathrm{E} 3) \mathrm{x}=0.060 ;(\mathrm{A4}-\mathrm{E} 4) \mathrm{x}=0.080$. 


\subsection{The Pitting Corrosion of X70 Carbon Steel in the $\mathrm{NaCl}$ Solution with $\mathrm{NaNO}_{2}$}

Figure 6 shows the pitting processes of the specimens at $E_{\mathrm{S}}=-0.080 \mathrm{~V}$ (the $E_{\mathrm{OCP}}$ is about $-0.330 \mathrm{~V}$ ) in $0.10 \mathrm{~mol} / \mathrm{L} \mathrm{NaCl}$ solutions containing various concentrations of $\mathrm{NaNO}_{2}$. As shown in Figure 6, with the increase in the concentration of $\mathrm{NaNO}_{2}$, both the number and the extent of the pits decreased, and the induced time of the pits increased. One current peak at the 20th min (B1) and two current peaks at the 30th $\min (\mathrm{C} 1)$ were observed on the surface of the specimen in the solution with $0.020 \mathrm{~mol} / \mathrm{L} \mathrm{NaNO}{ }_{2}$. However, the current peak did not appear until the 30th $\mathrm{min}(\mathrm{C} 2$ or C3) in the $\mathrm{NaCl}$ solution containing $0.040 \mathrm{~mol} / \mathrm{L}$ or $0.060 \mathrm{~mol} / \mathrm{L} \mathrm{NaNO}_{2}$. When the concentration of $\mathrm{NaNO}_{2}$ increased to $0.080 \mathrm{~mol} / \mathrm{L}$, current peak did not emerge until the 50 th $\mathrm{min}(\mathrm{E} 4)$. The experimental results also showed that $\mathrm{NaNO}_{2}$ inhibited both the number and the extent of the pits, and the inhibition efficiency increased with the concentrations. Similarly, the SEM images of the specimens (Figure 7) after 50 min anodic polarization at $E=-0.080 \mathrm{~V}$ in the $\mathrm{NaCl}$ solutions containing various concentrations of $\mathrm{NaNO}_{2}$ are consistent with the SECM images in Figure 6.
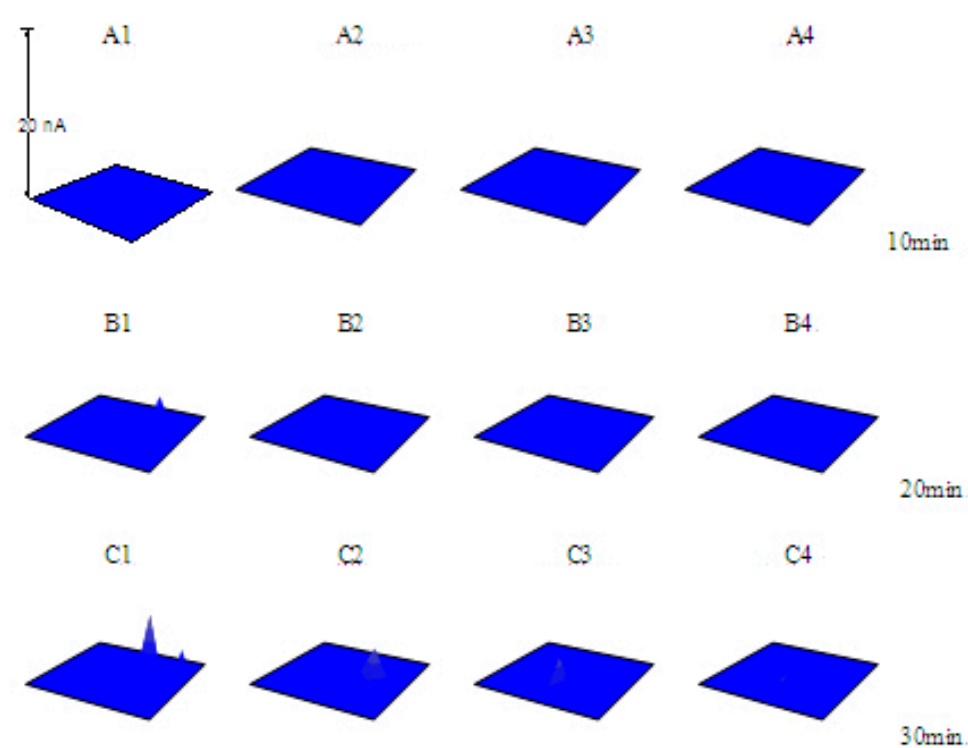

C2

c3

C4

D1
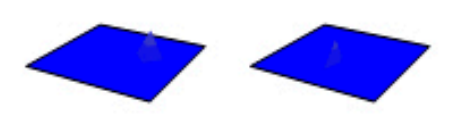

D2

D3
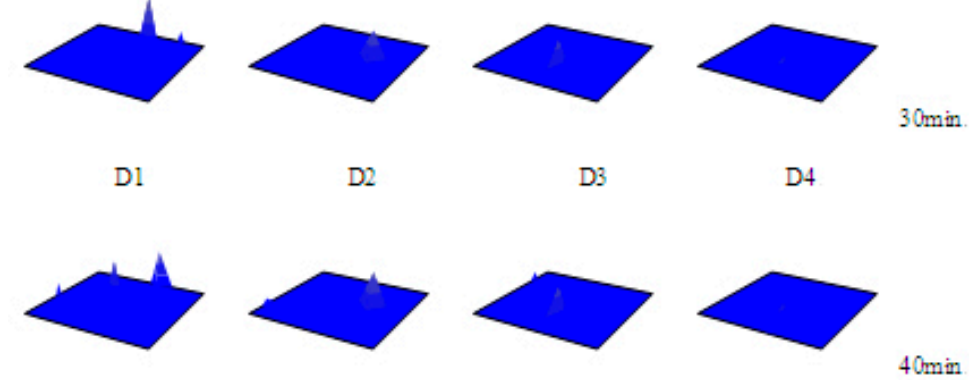

E2

E3

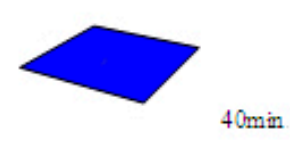

E1
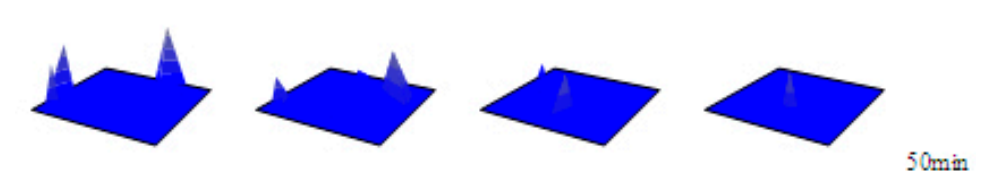

Figure 6. The SECM images of the $X 70$ carbon steel electrodes polarized at $-0.080 \mathrm{~V}\left(E_{\mathrm{OCP}}=-0.330 \mathrm{~V}\right)$ in $0.10 \mathrm{~mol} / \mathrm{L} \mathrm{NaCl}+\mathrm{x} \mathrm{mol} / \mathrm{L} \mathrm{NaNO}_{2}$ solutions $(\mathbf{A 1}-\mathrm{E} 1) \mathrm{x}=0.020 ;(\mathbf{A} 2-\mathrm{E} 2) \mathrm{x}=0.040 ;(\mathbf{A 3}-\mathrm{E} 3) \mathrm{x}=0.060$; $(\mathbf{A} 4-\mathrm{E} 4) \mathrm{x}=0.080$. 

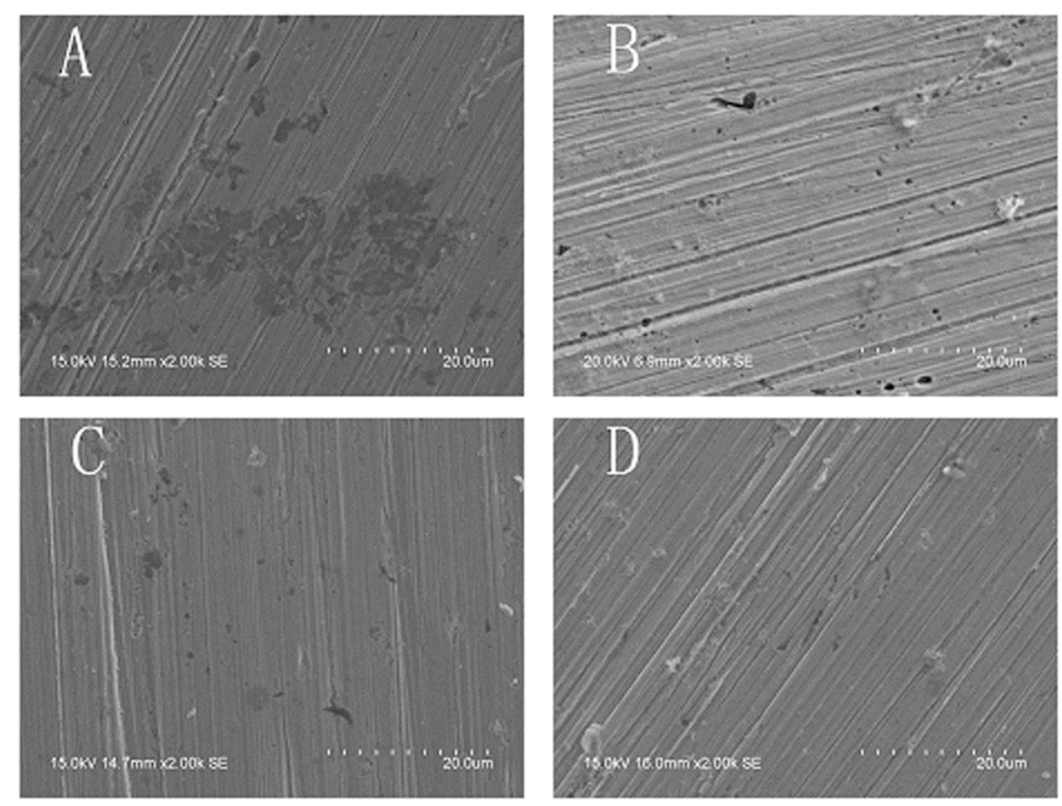

Figure 7. The surface morphology of the $\mathrm{X} 70$ carbon steel electrodes after $50 \mathrm{~min}$ polarization at -0.080 $\mathrm{V}\left(E_{\mathrm{OCP}}=-0.330 \mathrm{~V}\right)$ in $0.10 \mathrm{~mol} / \mathrm{L} \mathrm{NaCl}+\mathrm{x} \mathrm{mol} / \mathrm{L} \mathrm{NaNO}_{2}$ solutions $(\mathbf{A}) \mathrm{x}=0.020 ;(\mathbf{B}) \mathrm{x}=0.040$; (C) $\mathrm{x}=0.060 ;(\mathrm{D}) \mathrm{x}=0.080$.

\section{Discussion}

The results obtained by both the SECM and SEM measurements show that $\mathrm{Na}_{3} \mathrm{PO}_{4}$ and $\mathrm{NaNO}_{2}$ are both good inhibitors for $\mathrm{X} 70$ carbon steel in $0.10 \mathrm{~mol} / \mathrm{L} \mathrm{NaCl}$ solution.

In this study, the SECM equipment, as an in situ technology, was used to observe the dynamic processes of the pitting corrosion, and some detailed information could be obtained. For example, the SECM results indicated that not every current peak could propagate. Point "a" in Figure 5B1, which occurred at the 20th min and disappears at the 30th min, and it did not reappear anymore. During the anodic polarization of the electrodes, some current peaks disappear; others increase after their appearance, while new current peaks might occur at any time. In the competing processes of pits initiation and surface repassivation, some current peaks "died" and others "grew", which indicated the breakdown and the formation of the surface film on the electrode. The current peaks disappeared soon after their occurrence named "the metastable pits", which would be repassivated or developed to stable pits. A repassivated metastable pit might still be an active site for the following metastable pit to nucleate. The initiating and the propagating of the pits around a stable pit would cause accumulated corrosion damage, that is, a larger pit on the electrode surface might be composed of several smaller pits, as shown in Figures 4C and 5E1.

It is generally accepted that pitting corrosion is caused by the rupture of the surface film on the specimen. The rupture usually occurs at some unstable sites in the film, such as dislocation and so on. These sites are usually sensitive to $\mathrm{Cl}^{-}$ions. The adsorbed $\mathrm{Cl}^{-}$ions will displace the passive species (such as $\mathrm{OH}^{-}$and $\mathrm{H}_{2} \mathrm{O}$ dipoles) at the sites and, in turn, accelerate the local anodic dissolution. Thus, pitting corrosion occurs.

The inhibition effects of $\mathrm{PO}_{4}{ }^{3-}$ ions and $\mathrm{NO}_{2}{ }^{-}$ions are attributed by some investigators to their adsorption characteristics on the electrode surface. MacCafferty proposed a competitive adsorption model between $\mathrm{PO}_{4}{ }^{3-} / \mathrm{NO}_{2}{ }^{-}$ions and $\mathrm{Cl}^{-}$ions to explain the inhibition effects of the anions on the pitting corrosion [28]. The competitive adsorption of the inorganic anions with $\mathrm{Cl}^{-}$ions at the active sites on the electrode surface was considered as the reason for their inhibition. $\mathrm{NO}_{2}{ }^{-}$ions, $\mathrm{PO}_{4}{ }^{3-}$ ions and $\mathrm{Cl}^{-}$ions have the similar ionic electro-mobilities, therefore the two inorganic anions and the $\mathrm{Cl}^{-}$ ions may migrate into the growing micro-pits by electro-migration in the similar rates. The anions 
competitively migrated and adsorbed on the electrode surface, thereby slowing or preventing the increase in the concentration of $\mathrm{Cl}^{-}$ions on the steel surface and in the pit solution. Sakashita and Sato [24] suggested that the inorganic anions adsorbed on the steel surface possessed a strong cationic selectivity, which might repel the aggressive $\mathrm{Cl}^{-}$ions and protect the steel from being destroyed.

According to Zuo et al. [12], when the pitting corrosion of 316L SS occurred in the $\mathrm{NaCl}$ solution, in the pit solution, hydrolysis of $\mathrm{Na}_{3} \mathrm{PO}_{4}$ produced $\mathrm{HPO}_{4}{ }^{2-}, \mathrm{H}_{2} \mathrm{PO}_{4}{ }^{-}$and $\mathrm{H}_{3} \mathrm{PO}_{4}$. By the hydrolysis reaction, $\mathrm{H}^{+}$ions are consumed and $\mathrm{OH}^{-}$ions are produced. Thus, the $\mathrm{pH}$ value of the pit solution increased, the repassivation of the surface occurred and the electrodissolution in the pit decreased. Therefore, they concluded that the obvious inhibition effects of $\mathrm{Na}_{3} \mathrm{PO}_{4}$ on the pits growth resulted from the decreased pit solution acidity and the increased material passivity.

Figure 8 shows the SECM images during the 50 min anodic polarization process at $E=-0.300 \mathrm{~V}$ $\left(E_{\mathrm{OCP}}=-0.550 \mathrm{~V}\right)$ of the $X 70$ carbon steel electrode in $0.10 \mathrm{~mol} / \mathrm{L} \mathrm{NaCl}+0.010 \mathrm{~mol} / \mathrm{L} \mathrm{NaOH}$ solution $(\mathrm{pH}=2)$, which has the similar $\mathrm{pH}$ value with $0.10 \mathrm{~mol} / \mathrm{L} \mathrm{NaCl}$ solutions containing various concentrations of $\mathrm{Na}_{3} \mathrm{PO}_{4}$. Figure $5 \mathrm{~B}$ is the SEM image of the specimen after 50 min anodic polarization at $E=-0.300 \mathrm{~V}$ in the $\mathrm{NaCl}$ solution containing $0.010 \mathrm{~mol} / \mathrm{L} \mathrm{NaOH}$.

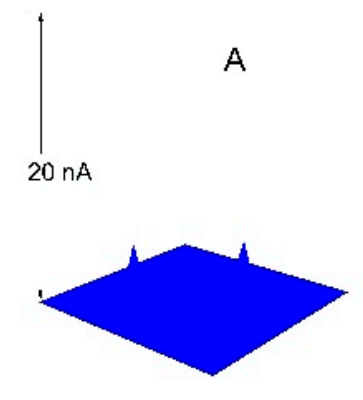

B

C

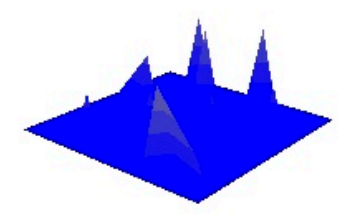

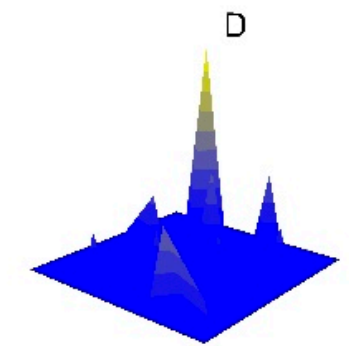
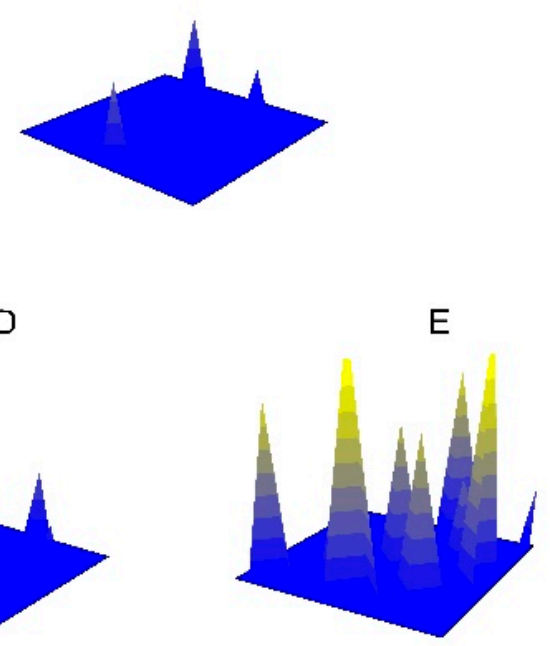

Figure 8. The SECM images of the $X 70$ carbon steel electrode polarized at $-0.300 \mathrm{~V}\left(E_{O C P}=-0.550 \mathrm{~V}\right)$ in $0.10 \mathrm{~mol} / \mathrm{L} \mathrm{NaCl}+0.010 \mathrm{~mol} / \mathrm{L} \mathrm{NaOH}$ solution (A) $10 \mathrm{~min}$; (B) $20 \mathrm{~min}$; (C) $30 \mathrm{~min}$; (D) $40 \mathrm{~min}$; (E) $50 \mathrm{~min}$.

When the $\mathrm{X} 70$ carbon steel specimen was in the $\mathrm{NaCl}$ solution containing $\mathrm{NaOH}$, the anodic dissolution occurred according to the following reactions:

$$
\begin{gathered}
\mathrm{Fe} \rightarrow \mathrm{Fe}^{2+}+2 \mathrm{e} \\
\mathrm{Fe}^{2+}+2 \mathrm{OH}^{-} \rightarrow \mathrm{Fe}(\mathrm{OH})_{2} \\
\mathrm{Fe}(\mathrm{OH})_{2}+2 \mathrm{Fe}^{2+}+2 \mathrm{H}_{2} \mathrm{O} \rightarrow \mathrm{Fe}_{3} \mathrm{O}_{4}+6 \mathrm{H}^{+}+2 \mathrm{e}^{-} .
\end{gathered}
$$

And $\mathrm{Fe}_{3} \mathrm{O}_{4}$ could convert to $\gamma-\mathrm{Fe}_{2} \mathrm{O}_{3}$, which would form compact films on the electrode surface and inhibit the pitting corrosion. 
Both the SECM images (Figures 5 and 8 ) and the SEM images (Figure 4B-F) indicate that the inhibition effects of $\mathrm{NaOH}$ are obviously weaker than those of $\mathrm{Na}_{3} \mathrm{PO}_{4}$. Therefore, the inhibition mechanism of $\mathrm{PO}_{4}{ }^{3-}$ ions is not equal to that of $\mathrm{OH}^{-}$ions.

$\mathrm{PO}_{4}{ }^{3-}$ ions can form iron phosphate with $\mathrm{Fe}^{2+}$ ions. Iron phosphate is a poorly soluble compound. Thus, the deposition of iron phosphate is beneficial to the formation of the passive film on the electrode surface. In this case, $\mathrm{PO}_{4}{ }^{3-}$ ions incorporated into the passive film, forming an improved stability against $\mathrm{Cl}^{-}$ions and thus retarding the corresponding destructive action. The experimental results by the electron diffraction method had shown that the protective film formed on the steel surface in the presence of $\mathrm{PO}_{4}{ }^{3-}$ ions was consist of a mixture of $\gamma-\mathrm{Fe}_{2} \mathrm{O}_{3}$ and $\mathrm{FePO}_{3} \cdot 2 \mathrm{H}_{2} \mathrm{O}[10,12]$. Therefore, the inhibition effects of $\mathrm{Na}_{3} \mathrm{PO}_{4}$ were the results of the adsorbed $\mathrm{PO}_{4}{ }^{3-}$ ions on the surface of the X70 carbon steel electrode contribute to not only the decreased pit solution acidity, but also the formation of the passive film by the deposition of iron phosphate.

According to the literature [13-18] and the experimental results (Figures 6 and 7), $\mathrm{NaNO}_{2}$ is a good anodic inhibitor, which oxidizes ferrous ions to ferric ions thereby makes the passive film more compact.

Fujioka et al. [16] had proposed that the inhibition effects of $\mathrm{NO}_{2}{ }^{-}$ions might be due to the fast reduction to $\mathrm{NH}_{4}{ }^{+}$during the steel dissolution reaction,

$$
\mathrm{NO}_{2}^{-}+6 \mathrm{e}+8 \mathrm{H}^{+} \rightarrow \mathrm{NH}_{4}^{+}+2 \mathrm{H}_{2} \mathrm{O} \text {. }
$$

The residual oxygen on the electrode surface promoted the oxidation of steel to produce $\mathrm{Fe}_{2} \mathrm{O}_{3}$ [13].

On the other hand, $\mathrm{NO}_{2}{ }^{-}$ions is classified as an intermediate base according to the HSAB (Hard-Soft-Acid-Basic) principle, and $\mathrm{Fe}^{2+}$ ions is an intermediate acid, $\mathrm{so}^{2} \mathrm{NO}_{2}^{-}$ions is preferentially combined with $\mathrm{Fe}^{2+}$ ions, which is the direct product of the electrochemical corrosion. And $\mathrm{NO}_{2}{ }^{-}$ions can oxidize $\mathrm{Fe}^{2+}$ ions to $\mathrm{Fe}^{3+}$ ions, a hard acid. $\mathrm{Fe}^{3+}$ ion tends to be combined with $\mathrm{O}^{2-}$ or $\mathrm{OH}^{-}$, a hard base, and thus a ferric compound is formed on the electrode surface. Then, the defects in the passive film can be repaired by the precipitation of the stable ferric compound. Therefore, $\mathrm{NO}_{2}{ }^{-}$ions suppress both the nucleation and the propagation of the pitting corrosion.

In a conclusion, it can be concluded that the inhibition effect of $\mathrm{PO}_{4}{ }^{3-}$ ions is mainly due to the formation of the salt film, while the corrosion inhibition of $\mathrm{NO}_{2}{ }^{-}$ions owes to the oxide film formed on the electrode surface. To verify the above conclusion further, the co-effects of the two anions on the corrosion behavior of $X 70$ carbon steel have been investigated.

Firstly, $\mathrm{Na}_{3} \mathrm{PO}_{4}\left(c_{\mathrm{a}}=0.040 \mathrm{~mol} / \mathrm{L}\right)$ or $\mathrm{NaNO}_{2}\left(\mathrm{c}_{\mathrm{b}}=0.040 \mathrm{~mol} / \mathrm{L}\right)$ or the two inhibitors $\left(c_{a}=0.030 \mathrm{~mol} / \mathrm{L}, c_{b}=0.010 \mathrm{~mol} / \mathrm{L} ; c_{a}=0.020 \mathrm{~mol} / \mathrm{L}, c_{b}=0.020 \mathrm{~mol} / \mathrm{L} ; c_{a}=0.010 \mathrm{~mol} / \mathrm{L}, c_{b}=0.030 \mathrm{~mol} / \mathrm{L}\right)$ were added into the $\mathrm{NaCl}$ solution, but the total concentration $(0.040 \mathrm{~mol} / \mathrm{L})$ of the inhibitor/inhibitors remained unchanged, and then the pitting resistances of the electrodes had been compared by the SECM measurements and the EIS. Figure 9 shows the SECM images of X70 carbon steel polarized at $-0.150 \mathrm{~V}\left(E_{\mathrm{OCP}}=-0.400 \mathrm{~V}\right)$ in various solutions. According to the SECM images, the pitting resistance of the specimen decreased when there were both of the anions in the same solution. The minimum pitting resistance was observed when the concentration of $\mathrm{PO}_{4}{ }^{3-}$ ions was equal to that of $\mathrm{NO}_{2}{ }^{-}$ ions. Figure 10 is the Nyquist plots of the EIS for X70 carbon steel in the solutions. The appropriate equivalent circuit is shown in Figure 11. The inhibition efficiency (P\%) is calculated according to the following formula:

$$
\mathrm{P} \%=\frac{R_{\mathrm{ct}}-R_{\mathrm{ct}}^{0}}{R_{\mathrm{ct}}} \times 100
$$




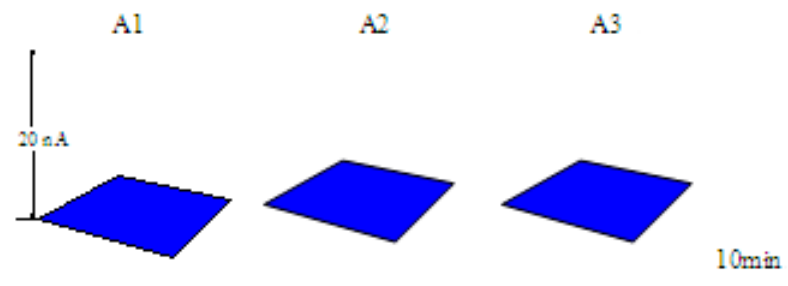

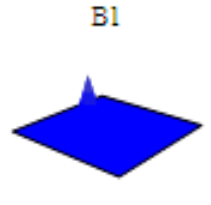

$\mathrm{C} 1$

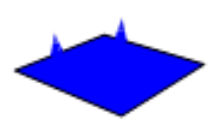

D1

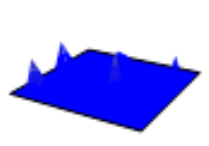

E1

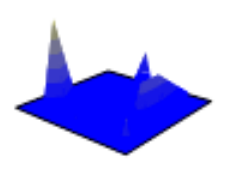

B2

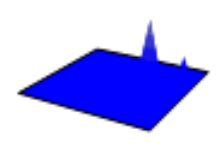

c2

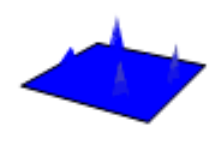

D2

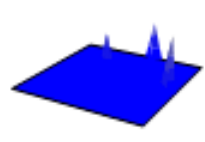

E2

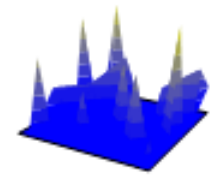

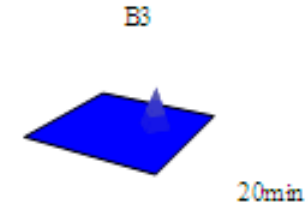

C3

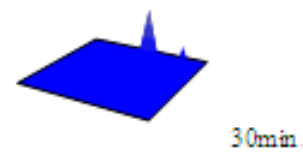

D3

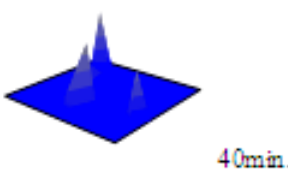

E3

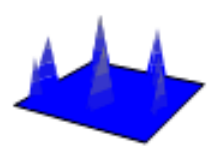

\section{$50 \mathrm{~min}$}

Figure 9. The SECM images of the $X 70$ carbon steel electrodes polarized at $-0.150 \mathrm{~V}\left(E_{O C P}=-0.400 \mathrm{~V}\right)$ in $0.10 \mathrm{~mol} / \mathrm{L} \mathrm{NaCl}+\mathrm{c}_{\mathrm{a}} \mathrm{mol} / \mathrm{L} \mathrm{Na} \mathrm{PO}_{4}+\mathrm{c}_{\mathrm{b}} \mathrm{mol} / \mathrm{L} \mathrm{NaNO}$ solutions $(\mathbf{A 1}-\mathrm{E1}) \mathrm{c}_{\mathrm{a}}=0.030, \mathrm{c}_{\mathrm{b}}=0.010$; $(\mathrm{A} 2-\mathrm{E} 2) \mathrm{c}_{\mathrm{a}}=0.020, \mathrm{c}_{\mathrm{b}}=0.020 ;(\mathrm{A} 3-\mathrm{E} 3) \mathrm{c}_{\mathrm{a}}=0.010, \mathrm{c}_{\mathrm{b}}=0.030$.

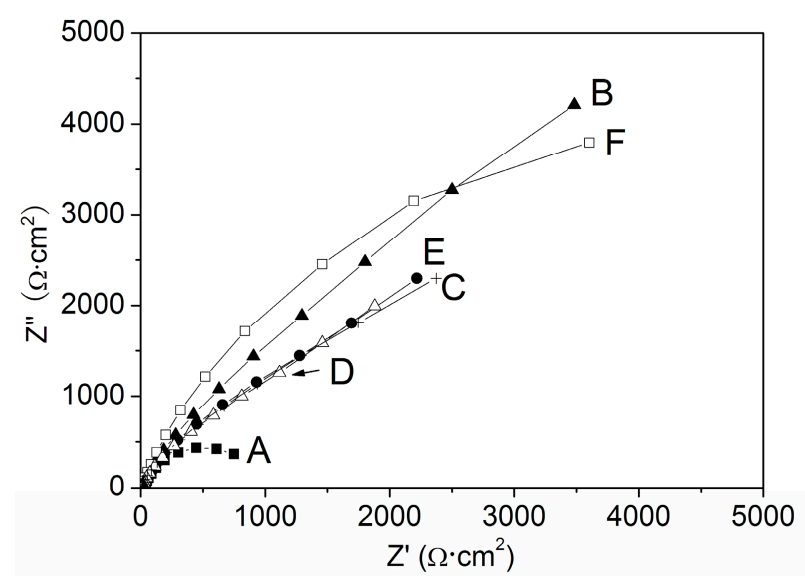

Figure 10. The Nyquist plots at the $E_{\mathrm{OCP}}$ for $X 70$ carbon steel electrodes in $0.10 \mathrm{~mol} / \mathrm{L} \mathrm{NaCl}+\mathrm{c}_{\mathrm{a}} \mathrm{mol} / \mathrm{L}$ $\mathrm{Na}_{3} \mathrm{PO}_{4}+\mathrm{c}_{\mathrm{b}} \mathrm{mol} / \mathrm{L} \mathrm{NaNO}$ solutions (A) $\mathrm{c}_{\mathrm{a}}=0, \mathrm{c}_{\mathrm{b}}=0 ;(\mathrm{B}) \mathrm{c}_{\mathrm{a}}=0.040, \mathrm{c}_{\mathrm{b}}=0 ;(\mathrm{C}) \mathrm{c}_{\mathrm{a}}=0.030, \mathrm{c}_{\mathrm{b}}=0.010$; (D) $c_{a}=0.020, c_{b}=0.020 ;(E) c_{a}=0.010, c_{b}=0.030 ;(F) c_{a}=0, c_{b}=0.040$. 


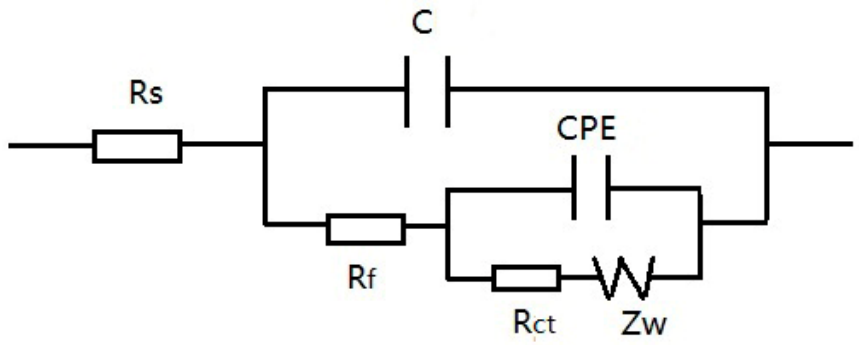

Figure 11. The equivalent circuit of the $\mathrm{X} 70$ carbon steel in $0.10 \mathrm{~mol} / \mathrm{L} \mathrm{NaCl}$ solution with $\mathrm{Na}_{3} \mathrm{PO}_{4}$ and/or $\mathrm{NaNO}_{2}$ inhibitor(s). Rs: solution resistance; Rf: film resistance; Rct: charge transfer resistance; C: double layer capacitance; CPE: constant phase element; Zw: Warburg impedance.

$R_{\mathrm{ct}}$ and $R_{\mathrm{ct}}^{0}$ are the charge transfer resistances for the electrodes in $0.10 \mathrm{~mol} / \mathrm{L} \mathrm{NaCl}$ solution with and without inhibitor(s) respectively. The data of $R_{\mathrm{ct}}$ and $\mathrm{P} \%$ are fitted in Table 1 . It can be seen that $R_{\mathrm{ct}}$ and $\mathrm{P} \%$ decreased when there were both $\mathrm{NO}_{2}{ }^{-}$ions and $\mathrm{PO}_{4}{ }^{3-}$ ions in the same solution. The minimum $R_{\mathrm{ct}}$ and $\mathrm{P} \%$ were observed when the concentration of $\mathrm{PO}_{4}{ }^{3-}$ ions was equal to that of $\mathrm{NO}_{2}{ }^{-}$ions.

Table 1. Effects of sodium phosphate and/or sodium nitrite on the $R_{\mathrm{ct}}$ and $\mathrm{P} \%$ of $\mathrm{X} 70$ carbon steel in $0.10 \mathrm{~mol} / \mathrm{L} \mathrm{NaCl}+c_{\mathrm{a}} \mathrm{mol} / \mathrm{L} \mathrm{Na} \mathrm{PO}_{4}+\mathrm{c}_{\mathrm{b}} \mathrm{mol} / \mathrm{L} \mathrm{NaNO}$ solutions $\left((\mathrm{A}) \mathrm{c}_{\mathrm{a}}=0, \mathrm{c}_{\mathrm{b}}=0 ;\right.$; (B) $\mathrm{c}_{\mathrm{a}}=0.040, \mathrm{c}_{\mathrm{b}}=0$; (C) $\left.c_{a}=0.030, c_{b}=0.010 ;(D) c_{a}=0.020, c_{b}=0.020 ;(E) c_{a}=0.010, c_{b}=0.030 ;(F) c_{a}=0, c_{b}=0.040\right)$.

\begin{tabular}{ccccccc}
\hline Solution & A & B & C & D & E & F \\
\hline$R_{\mathrm{ct}} / \Omega \cdot \mathrm{cm}^{2}$ & 1064 & 3316 & 2172 & 1784 & 2109 & 3408 \\
$\mathrm{P} \%$ & - & 67.91 & 51.01 & 40.36 & 49.55 & 68.78 \\
\hline
\end{tabular}

Secondly, the X70 carbon steel electrode was polarized in $\alpha \mathrm{mol} / \mathrm{L} \mathrm{Na}_{3} \mathrm{PO}_{4}+\beta \mathrm{mol} / \mathrm{L} \mathrm{NaNO}{ }_{2}$ mixed solution respectively $(\alpha=0.040, \beta=0 ; \alpha=0.030, \beta=0.010 ; \alpha=0.020, \beta=0.020 ; \alpha=0.010$, $\beta=0.030 ; \alpha=0, \beta=0.040$ ) at the potential of $E=0.500 \mathrm{~V}$ for $10 \mathrm{~min}$, then the electrode was transferred to $0.10 \mathrm{~mol} / \mathrm{L} \mathrm{NaCl}$ solution, and then the EIS measurements had been carried out. As shown in Figure 12, the pitting impedance decreased for the electrodes polarized in the mixed solutions, and when the concentrations of the two anions were equal, the lowest pitting impedance had been observed $0.10 \mathrm{~mol} / \mathrm{L} \mathrm{NaCl}$ solution. In each plot, the real part at low frequency contracts, which showed a compact film formed on the surface of the X70 carbon steel specimen.

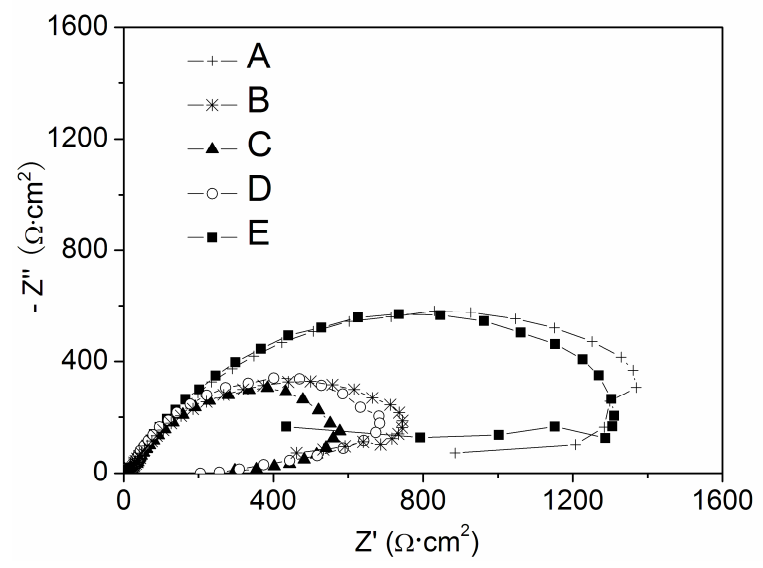

Figure 12. The Nyquist plots in $0.10 \mathrm{~mol} / \mathrm{L} \mathrm{NaCl}$ solutions at the $E_{\mathrm{OCP}}$ of $\mathrm{X} 70$ carbon steel electrodes after $10 \mathrm{~min}$ anodic polarization at $0.500 \mathrm{~V}$ in $\alpha \mathrm{mol} / \mathrm{L} \mathrm{Na}_{3} \mathrm{PO}_{4}+\beta \mathrm{mol} / \mathrm{L} \mathrm{NaNO}$ solutions (A) $\alpha=0.040$, $\beta=0$; (B) $\alpha=0.030, \beta=0.010$; (C) $\alpha=0.020, \beta=0.020$; (D) $\alpha=0.010, \beta=0.030$; (E) $\alpha=0, \beta=0.040$. 
If there were both $\mathrm{NO}_{2}{ }^{-}$ions and $\mathrm{PO}_{4}{ }^{3-}$ ions in the same solution, $\mathrm{NO}_{2}{ }^{-}$ions might displace $\mathrm{PO}_{4}{ }^{3-}$ ions on the surface of the electrode. Therefore, the pitting resistance of the specimen decreased when there were both of the two anions in the same solution for the anions compete against each other to adsorb on the electrode, that is, the salt film would prevent the formation of the oxide film, and vice versa. When there was only one type of film, the film was stable, and when two different types of film co-existed at the same time, the interface between the two films was very active and vulnerable to the corrosive media. Moreover, under the same concentration, the interface was the least stable, and the lowest inhibition efficiency was observed.

\section{Conclusions}

The inhibition effects of $\mathrm{Na}_{3} \mathrm{PO}_{4}$ and $\mathrm{NaNO}_{2}$ on the pitting corrosion processes of $\mathrm{X} 70$ carbon steel in $0.10 \mathrm{~mol} / \mathrm{L} \mathrm{NaCl}$ solution have been investigated.

To study the inhibition effects, SECM, which has high spatial resolution, has demonstrated its advantage over the traditional electrochemical techniques (EIS, Tafel curves and SEM and so on) by obtaining the transient current distribution images on the electrode surface. During the pitting corrosion, using SECM, the dynamic processes of the dissolution and the repair of the passive film on the electrode surface, the transformation between the metastable pits and the stable pits, the distribution of the corrosion products, the effects of the inhibitors on the dynamic processes and more information concerning the inhibition mechanisms can be obtained.

In this study, the inhibition effects and mechanisms of $\mathrm{PO}_{4}{ }^{3-}$ ions and $\mathrm{NO}_{2}{ }^{-}$ions proposed by the reporting papers are verified by the SECM measurements. The inhibition efficiency of the two anions increases with their concentrations. The inhibition effect of $\mathrm{PO}_{4}{ }^{3-}$ ions is due to their competitive adsorption with $\mathrm{Cl}^{-}$ions at active surface sites, the decrease of the pits solution acidity and the formation of the salt film by the deposition of the iron phosphate. However, the inhibition behavior of $\mathrm{NO}_{2}{ }^{-}$ions is resulted from their competitive adsorption with $\mathrm{Cl}^{-}$ions and their strong oxidizing abilities.

Author Contributions: Conceptualization, Y.Z., and L.L.; methodology, J.Z.; software, J.Z.; validation, Y.Z., data curation, Y.Z., and J.D.; writing-original draft preparation, Y.Z.; writing-review and editing, Y.Z., and J.D.; supervision, L.L.; project administration, Y.Z., All authors have read and agreed to the published version of the manuscript.

Funding: This research was funded by National Natural Science Foundation of China (No. 21303077).

Acknowledgments: We would like to thank a Project Funded by the Priority Academic Program Development of Jiangsu Higher Education Institutions.

Conflicts of Interest: The authors declare no conflict of interest.

\section{References}

1. Štefec, R.; Franz, F. A study of the pitting corrosion of cold-worked stainless steel. Corros. Sci. 1978, 18, 161-168. [CrossRef]

2. Alvarez, M.G.; Galvele, J.R. The mechanism of pitting of high purity iron in $\mathrm{NaCl}$ solutions. Corros. Sci. 1984, 24, 27-48. [CrossRef]

3. Mizuno, T. In-situ analysis of chloride ion concentration within pits during pitting of iron. Corros. Sci. 1990, 31, 497-502. [CrossRef]

4. Newman, R.C.; Sieradzki, K. Metallic Corrosion. Science 1994, 263, 1708-1709. [CrossRef] [PubMed]

5. Punckt, C.; Bölscher, M.; Rotermund, H.H.; Mikhailov, A.S.; Organ, L.; Budiansky, N.; Scully, J.R.; Hudson, J.L. Sudden onset of pitting corrosion on stainless steel as a critical phenomenon. Science 2004, 305, 1133-1136. [CrossRef]

6. Cheng, Y.F.; Wilmott, M.; Luo, J.L. The role of chloride ions in pitting of carbon steel studied by the statistical analysis of electrochemical noise. Appl. Surf. Sci. 1999, 152, 161-168. [CrossRef] 
7. Li, L.; Wang, C.; Yuan, B.Y.; Chen, S.H. Numerical reconstruction of digital holograms for the study of pitting dynamic processes of the $\mathrm{X} 70$ carbon steel in $\mathrm{NaCl}$ solution. Electrochem. Commun. 2008, 10, 103-107. [CrossRef]

8. Tang, Y.W.; Dai, N.W.; Wu, J.; Jiang, Y.M.; Li, J. Effect of surface roughness on pitting corrosion of 2205 duplex stainless steel investigated by electrochemical noise measurements. Materials 2019, 12, 738. [CrossRef]

9. Yang, Z.X.; Kan, B.; Li, J.X.; Qiao, L.J.; Volinsky, A.A.; Su, Y.S. A statistical study on the effect of hydrostatic pressure on metastable pitting corrosion of X70 pipeline steel. Materials 2017, 10, 1307. [CrossRef]

10. Refaey, S.A.M.; Abd El-Rehim, S.S.; Taha, F.; Saleh, M.B.; Ahmed, R.A. Inhibition of chloride localized corrosion of mild steel by $\mathrm{PO}_{4}{ }^{3-}, \mathrm{CrO}_{4}{ }^{2-}, \mathrm{MoO}_{4}{ }^{2-}$, and $\mathrm{NO}_{2}{ }^{-}$anions. Appl. Surf. Sci. 2000, 158, 190-196. [CrossRef]

11. Refaey, S.A.M. Inhibition of steel pitting corrosion in $\mathrm{HCl}$ by some inorganic anions. Appl. Surf. Sci. 2005, 240, 396-404. [CrossRef]

12. Zuo, Y.; Wang, H.T.; Zhao, J.M.; Xiong, J.P. The effects of some anions on metastable pitting of 316L stainless steel. Corros. Sci. 2002, 44, 13-24. [CrossRef]

13. Zhou, Y.; Zuo, Y. The inhibitive mechanisms of nitrite and molybdate anions on initiation and propagation of pitting corrosion for mild steel in chloride solution. Appl. Surf. Sci. 2015, 353, 924-932. [CrossRef]

14. Eyu, G.D.; Will, G.; Dekkers, W.; Macleod, J. The Synergistic Effect of Iodide and Sodium Nitrite on the Corrosion Inhibition of Mild Steel in Bicarbonate-Chloride Solution. Materials 2016, 9, 868. [CrossRef] [PubMed]

15. Liu, L.; Xu, Y.; Wang, X.; He, L.; Huang, Y. Preferential Corrosion Behavior of Carbon Steel Weld in Simulation Pore Solution and the Inhibition Performance of Nitrite. Mater. Rep. 2017, 31, 119-124.

16. Fujioka, E.; Nishihara, H.; Aramaki, K. The inhibition of pit nucleation and growth on the passive surface of iron in a borate buffer solution containing Cl- by oxidizing inhibitors. Corros. Sci. 1996, 38, 1915-1933. [CrossRef]

17. Refaey, S.A.M.; Abd El Rehim, S.S. Inhibition of chloride pitting corrosion of tin in alkaline and near neutral medium by some inorganic anions. Electrochim. Acta 1996, 42, 667-674. [CrossRef]

18. Reffass, M.; Sabot, R.; Jeannin, M.; Berziou, C.; Refait, P. Effects of $\mathrm{NO}_{2}{ }^{-}$ions on localised corrosion of steel in $\mathrm{NaHCO}_{3}+\mathrm{NaCl}$ electrolytes. Electrochim. Acta 2007, 52, 7599-7606. [CrossRef]

19. Reffass, M.; Sabot, R.; Jeannin, M.; Berziou, C.; Refait, P. Effects of phosphate species on localised corrosion of steel in $\mathrm{NaHCO}_{3}+\mathrm{NaCl}$ electrolytes. Electrochim. Acta 2009, 54, 4389-4396. [CrossRef]

20. Cheng, Y.F.; Rairdan, B.R.; Luo, J.L. Features of electrochemical noise generated during pitting of inhibited A516-70 carbon steel in chloride solutions. J. Appl. Electrochem. 1998, 28, 1371-1375. [CrossRef]

21. Dong, Z.H.; Guo, X.P.; Zheng, J.X.; Xu, L.M. Investigation on inhibition of $\mathrm{CrO}_{4}{ }^{2-}$ and $\mathrm{MoO}_{4}{ }^{2-}$ ions on carbon steel pitting corrosion by electrochemical noise analysis. J. Appl. Electrochem. 2002, 32, 395-400. [CrossRef]

22. Cheng, Y.F.; Luo, J.L. Passivity and pitting of carbon steel in chromate solutions. Electrochim. Acta 1999, 44, 4795-4804. [CrossRef]

23. Hancock, P.; Mayne, J.E.O. The inhibition of the corrosion of iron in the neutral and alkaline solutions. J. Appl. Chem. 1959, 9, 345-352. [CrossRef]

24. Sakashita, M.; Sato, N. The effect of molybdate anion on the ion-selectivity of hydrous ferric oxide films in chloride solutions. Corros. Sci. 1977, 17, 473-486. [CrossRef]

25. El Dahan, H.A. Pitting corrosion inhibition of 316 stainless steel in phosphoric acid-chloride solutions. J. Mater. Sci. 1999, 34, 851-857. [CrossRef]

26. Virtanen, S.; Surber, B.; Nylund, P. Influence of $\mathrm{MoO}_{4}{ }^{2-}$ anion in the electrolyte on passivity breakdown of iron. Corros. Sci. 2001, 43, 1165-1177. [CrossRef]

27. Zhao, J.M.; Zuo, Y. The effects of molybdate and dichromate anions on pit propagation of mild steel in bicarbonate solution containing $\mathrm{Cl}^{-}$. Corros. Sci. 2002, 44, 2119-2130. [CrossRef]

28. MacCafferty, E. A competitive adsorption model for the inhibition of crevice corrosion and pitting. J. Electrochem. Soc. 1990, 137, 3731-3740. [CrossRef]

29. Tang, Y.M.; Zuo, Y.; Zhao, H. The current fluctuations and accumulated pitting damage of mild steel in $\mathrm{NaNO}_{2}-\mathrm{NaCl}$ solution. Appl. Surf. Sci. 2005, 243, 82-88. [CrossRef]

30. Yuan, Y.; Li, L.; Wang, C.; Zhu, Y.Y. Study of the effects of hydrogen on the pitting processes of X70 carbon steel with SECM. Electrochem. Commun. 2010, 12, 1804-1807. [CrossRef] 
31. Simőes, A.M.; Bastos, A.C.; Ferreira, M.G.; González-García, Y.; González, S.; Souto, R.M. Use of SVET and SECM to study the galvanic corrosion of an iron-zinc cell. Corros. Sci. 2007, 49, 726-739. [CrossRef]

32. Zhu, R.K.; Luo, J.L. Investigation of stress-enhanced surface reactivity on Alloy 800 using scanning electrochemical microscopy. Electrochem. Commun. 2010, 12, 1752-1755. [CrossRef]

Publisher's Note: MDPI stays neutral with regard to jurisdictional claims in published maps and institutional affiliations.

(C) 2020 by the authors. Licensee MDPI, Basel, Switzerland. This article is an open access article distributed under the terms and conditions of the Creative Commons Attribution (CC BY) license (http://creativecommons.org/licenses/by/4.0/). 